\title{
STRATEGI DINAS PENDIDIKAN DAN KEBUDAYAAN PROVINSI LAMPUNG DALAM MELESTARIKAN BAHASA DAN AKSARA LAMPUNG
}

\author{
Oleh: \\ Ayu Nadia Pramazuly, S.I.P.,M.I.P. \\ Muhammad Mirsa Faisal \\ Program Studi Administrasi Publik, Universitas Tulang Bawang Lampung \\ e-Mail: ayunadiapramazuly@gmail.com
}

\begin{abstract}
ABSTRAK
Provinsi Lampung memiliki bahasa dan aksara daerah yaitu bahasa dan aksara Lampung, akan tetapi pada penggunaannya mengalami degradasi. Diperlukan strategi yang baik dalam melestarikan bahasa dan aksara lampung oleh Dinas Pendidikan dan Kebudayaan Provinsi Lampung. Tujuan dari penelitian ini adalah untuk menganalisa; 1). Strategi yang dilakukan Dinas Pendidikan dan Kebudayaan Provinsi Lampung dalam melestarikan Bahasa dan Aksara Lampung. 2). Terindentifikasinya Kendala-kendala yang menghambat Dinas Pendidikan dan Kebudayaan Provinsi Lampung dalam melestarikan Bahasa dan Aksara Lampung.

Jenis penelitian ini adalah penelitian deskriptif dengan pendekatan kualitatif. Hasil penelitian adalah sebagai berikut: 1). Program Disdikbud sudah cukup baik namun belum maksimal 2). Gaya kepemimpinan di Disdikbud yaitu bersifat konsultatif, a danya penerapan komunikasi dua arah. 3). Manajemen SDM dan kultur organisasi melalui pembagian kerja (struktur), Standar Operasional Prosedur (SOP), teknologi fingerprint dan In House Training untuk SDM.

Peneliti merekomendasikan beberapa hal, yaitu: 1). Pemprov hendaknya menambah anggaran dan SDM Disdikbud. 2). Program Disdikbud terkait pelestarian bahasa dan aksara Lampung melibatkan partisipasi masyarakat 3). Disdikbud seharusnya mengadakan kerjasama dalam menyusun Renstra dan Program dengan stakeholder dalam upaya pelestarian. 4). Disdikbud hendaknya memanfaatkan situs jejaring sosial dalam proses sosialisasi program. 5). Konten program aplikasi Kaganga seharusnya dilengkapi juga dengan kamus Bahasa Lampung atau konten Bahasa Lampung. 6). Dalam menyusun perencanaan program hendaknya Dinas merincikan antara tujuan, sasaran, waktu, jumlah anggaran yang diperlukan serta jumlah pelaksana atau penanggung jawab program.
\end{abstract}

Kata kunci: manajemen strategi, implementasi strategi, pelestarian bahasa dan aksara

\section{PENDAHULUAN}

\subsection{Latar Belakang}

Bahasa daerah mempunyai fungsi strategis dalam dunia pendidikan dan pembangunan karakter serta jati diri bangsa Dalam kaitan itulah, perlu ditempuh langkah suatu kebijaksanaan oleh pemda. Dengan demikian, upaya pembinaan 2 dan pengembangan bahasa daerah dapat terus berdaya guna dan berhasil guna dan hidup di tengah masyarakat sehari-hari.

Provinsi Lampung memiliki bahasa daerah yaitu bahasa Lampung, yang merupakan 
salah satu bahasa daerah di kepulauan nusantara yang masih hidup dan dipakai oleh masyarakat penuturnya, terutama sebagai bahasa intrasuku. Selain sebagai bahasa bahasa pergaulan intrasuku, Bahasa Lampung juga masih dipakai dalam upacara-upacara adat, seperti upacara pernikahan, pemberian nama atau pemberian gelar, khitanan serta upacara etnis lainnya. Bahasa Lampung juga mempunyai dua jenis, yaitu dialek nyo atau O "apa" dan dialek api atau A "apa". Masyarakat, yang dalam ilmu bahasa, memberikan untuk dialek-dialek tersebut. Mereka menamakan dialek tersebut dengan kelompok masyarakat yang mendiami wilayah tertentu, misalnya dialek Abung, Tulang Bawang, Pubian, Pesisir, Pemanggilan, Jelma Daya, Sungkay, dan Way Kanan.

Provinisi Lampung memiliki bentuk tulisan yang disebut Aksara Lampung. Mengingat Aksara Lampung merupakan tujuh aksara di indonesia yang sampai saat ini masih tersisa dan masih diakui keberadaanya, bentuk tulisan tersebut memiliki hubungan dengan aksara Pallawa dari India Selatan. Macam tulisannya fonetik berjenis suku kata yang merupakan huruf hidup seperti dalam Huruf Arab, dengan menggunakan tanda-tanda fathah pada baris atas dan tanda-tanda kasrah pada baris bawah, tetapi tidak menggunakan tanda dammah pada baris depan, melainkan menggunakan tanda di belakang, di mana masing-masing tanda mempunyai nama tersendiri. Bakr $\mathrm{H}$. Baheram dalam Titik Pudjiastuti (1995: 58). 3 Keberadaan Bahasa dan Aksara Lampung dari hari ke hari serta tahun ke tahun semakin terasingkan, Kita harus menerima bahwa masyarakat suku asli Lampung saat ini adalah minoritas di Provinsi Lampung. Berikut ini adalah data yang menunjukkan jumlah penutur bahasa di Provinsi Lampug.
Tabel 1.1 Jumlah Penutur Bahasa di Provinsi lampung

\begin{tabular}{|l|l|l|}
\hline No & \multicolumn{1}{|c|}{ Penutur } & Persentase \\
\hline 1 & Bahasa jawa & $61,88 \%$ \\
\hline 2 & Bahasa Lampung & $11,92 \%$ \\
\hline 3 & Bahasa Sunda & $11,27 \%$ \\
\hline 4 & $\begin{array}{l}\text { Bahasa bengkulu, } \\
\text { Batak, Minang } \\
\text { dan Lain-lain }\end{array}$ & $11,35 \%$ \\
\hline
\end{tabular}

Sumber : Dinas Pendidikan Provinsi Lampung th 2019

Dari tabel 1 di atas terlihat jelas bahwa masyarakat pendatang sangat mendominasi terutama suku jawa. Masyarakat pribumi dapat dikatakan sangat minim jumlah penuturnya. Masyarakat pendatang hidup berkelompok dalam komunitasnya dengan budaya dan bahasanya, sehingga yang terjadi Bahasa Lampung saat ini mulai teralih. Mengingat, persentase penduduk yang bisa terkategorikan sebagai minoritas di tanah sendiri.

Pihak Pemerintah Provinsi melalui Dinas Pendidikan dan Kebudayaan Provinsi Lampung sudah memiliki beberapa dokumen peraturan, yaitu:

1) Peraturan Gubernur nomor 2 tahun 2008,

2) Peraturan Gubernur nomor 4 tahun 2011 dan

3) Peraturan Gubernur nomor 39 tahun 2014.

Dokumen peraturan-peraturan tersebut merupakan pedoman untuk melaksanakan upaya pelestarian dan pengembangan bahasa dan Aksara Lampung sebagai penguat eksistensi kebudayaan. Bahasa Lampung selama ini diajarkan di jenjang sekolah dasar hingga menengah. Tetapi, 
hasilnya memang belum maksimal. Pengajaran Bahasa Lampung terlalu 5 mengacu pada pembelajaran aksara. Siswa mampu membaca dan menulis dalam aksara Lampung. Tetapi, tidak mampu menggunakannya untuk komunikasi. Setelah siswa lulus dari SD dan SMP mereka juga bisa dipastikan lupa lagi aksara-aksara tersebut, apalagi bahasanya. Sebab, memang tidak pernah dipakai secara aktif untuk berkomunikasi baik lisan maupun tulisan di masyarakat.

Penyediaan guru Bahasa Lampung yang berkompeten belum menjadi perhatian serius pemerintah. Semenjak Program Studi D III Bahasa Lampung di Universitas Lampung ditutup di tahun 2007, kurangnya peminat dan lapangan pekerjaan yang tersedia untuk lulusannya, sekolah-sekolah pun terlihat bingung mencari guru yang memiliki kualifikasi mengajar Bahasa Lampung mulai kelas 4 SD sampai 9 SMP. Yang kemudian terjadi adalah meminta guru yang bersuku Lampung atau bisa Berbahasa Lampung, tanpa memperdulikan latar belakang pendidikannya, untuk mengajar Bahasa Lampung. Dapat dipastikan hasilnya tidak maksimal, dikarenakan guru-guru tersebut tidak memiliki latar belakang pengajaran bahasa.

Menurut Ketua MGMP Bahasa Lampung, Lampung masih kekurangan 6.300-an guru Bahasa Lampung. Selain pelaksanaan Peraturan Gubernur (Pergub) Lampung Nomor 39 Tahun 2014 tentang Implementasi Pembelajaran Bahasa dan Aksara Lampung Tingkat SD/MI, SMP/MTs, dan SMA/MA/SMK belum maksimal juga sebenarnya sudah ada Peraturan Daerah Nomor 2 Tahun 2008 tentang Pemeliharaan Kebudayaan Lampung, namun lagi dan lagi Implementasinya masih dibilang sangat kurang. melihat jumlah sekolah di
Lampung ada 8 ribuan dari SD, SMP, dan SMA/SMK idealnya 1 sampai 2 guru Bahasa Lampung di satu sekolah dan ternyata belum semuanya ada.

\subsection{Pertanyaan Penelitian}

Melalui latar belakang diatas, maka peneliti menggunakan pertanyaan penelitian untuk mengetahui:

1. Bagaimana pelkasanaan Strategi Dinas Pendidikan dan Kebudayaan Provinsi Lampung dalam melestarikan Bahasa dan Aksara Lampung?

2. Apa saja kendala0kendala yang dihadapi Dinas Pendidikan dan Kebudayaan Provinsi Lampung dalam Melesetarikan Bahasa dan Aksara Lampung?

\subsection{Tujuan dan Manfaat Penelitian}

\subsubsection{Tujuan Penelitian}

Adapun tujuan dalam penelitian ini adalah:

1. Mendapatkan penjelasan tentang pelaksanaan Strategi yang dilakukan Dinas Pendidikan dan Kebudayaan Provinsi Lampung dalam melestarikan Bahasa dan Aksara Lampung

2. Teridentifikasinya kendala-kendala yang menghambat Dinas Pendidikan dan Kebudayaan Provinsi Lampung dalam melestarikan Bahasa dan Aksara Lampung

\subsubsection{Manfaat Penelitian}

Adapun Manfaat dalam Penelitian ini adalah:

1. Manfaat Teoritis

Hasil penelitian ini diharapkan mampu memberikan kontribusi terhadap perkembangan kajian Ilmu Administrasi Negara, khususnya studi tentang manajemen strategis sektor 
publik sehingga dapat memperkuat teori-teori tentang manajemen strategi.

2. Manfaat Praktis

Hasil penelitian ini diharapkan mampu memberikan masukan dan tambahan informasi bagi Dinas Pendidikan dan Kebudayaan Provinsi Lampung serta masyarakat Lampung guna melestarikan Bahasa dan Aksara Lampung

\section{KAJIAN PUSTAKA KERANGKA PIKIR}

\subsection{Pendekatan Teori}

\subsubsection{Tinjauan Tentang Strategi}

Strategi dibuat oleh pengambil keputusan (administrasi negara) untuk menentukan langkah yang tepat dalam penyelesaian masalah yang sedang dihadapi. Strategi yang dibuat harus diimplementasikan dalam penyelesaian masalah sehingga tolak ukur strategi akan dapat diukur dari implementasinya.

McNichols dalam J.Salusu (2006:101) "strategi ialah suatu seni menggunakan kecakapan dan sumber daya suatu organisasi untuk mencapai sasarannya melalui hubungannya yang efektif dengan lingkungan dalam kondisi yang paling menguntungkan".

Wechsler dan backoff dalam Heene,dkk (2010:62), menekankan bahwa terbuka peluang untuk mengidentifikasi dalil-dalil yang memungkinkan kategori penerapan organisasi publik kedalam empat corak persilangan. Mengenai ciri spesifik dari empat jenis strategi publik yang telah teridentifikasi oleh Wechsler dan Backoff dalam Heene,dkk (2010:63) dapat diilustrasikan sebagai berikut:

1. Strategi Ekspansi
Didalam strategi ekspansi penerapan strategi terutama sekali ditunjukan bagi peningkatan status, kapasitas, serta saranasarana yang berdampak mampu memberi sentuhan ewarna masa depan keorganisasian yang selaras zaman.

\section{Strategi Transformasi}

Pada strategi ini ditandai oleh adanya kebutuhan drai organisasi untuk memenuhi tekanan internal maupun eksternal, yang ada prinsipnya dilakukan demi terjadinya perubahan fundamental.

\section{Strategi Isolasi}

Strategi isolasi yang memiliki ciri adanya penolakan aktif terhadap tekanan eksternal yang tengah dihadapi oleh organisasi.

\section{Strategi Politisasi}

Didalam strategi politisasi mengenal dua perwujudan. Pada perwujudan yang pertama, strategi organisasi ditujukan untuk menciptakan terbentuknya keseimbangan kekuatan yang baru didalam suatu lingkungan politik strategi yang dimunculkan dari organisasi tersebut.

\subsubsection{Tinjauan Tentang Manajemen Strategi}

Beberapa ahli dalam ilmu manajeman untuk menetukan manajemen strategi dengan cara yang berbeda. Ketchen (2009) mendefinisikan analisis manajemen strategis keputusan dan tindakan oleh perusahaan untuk menciptakan dan mempertahankan keunggulan kompetitif.

Adapun tujuan manajemen strategi adalah:

1. Melaksanakan dengan mengevalasi strategi yang dipilih secara efektif dan efisien.

2. Mengevaluasi kinerja, meninjau dan mengkaji ulang situasi serta melakukan 
berbagai penyesuaian dan koreksi jika terdapat penyimpangan didalam pelaksanaan strategi.

3. Senentiasa meninjau kembali kekuatan, kelemahan, peluang dan ancaman yang ada.

Adapun manfaat manajemen strategi adalah:

Menurut Greenley menyatakan manajemen strategis memberikan manfaat sebagai berikut:

1. Memungkinkan untuk identifikasi, penentuan prioritas,dan eksploitasi peluang.

2. Memberikan pandangan objektif atas masalah manajemen.

3. Mempresentasikan kerangka kerja unntuk aktivitas kontrol dan koordinasi yang lebih baik.

4. Meminimalkan efek dari kondisi dan perubahan yang jelek.

5. Memungkinkan agar keputusan besar dapat mendukung dengan lebih baik tujuan yang telah ditetapkan.

6. Memungkinkan alokasi sumber daya dan waktu yang lebih sedikit untuk mengkoreksi keputusan yang salah atau tidak terencana.

7. Menciptakann kerangka kerja untuk komunikasi internal diantara staff.

8. Memberikan dasar untuk mengklarifikasi tanggungjawab individu.

9. Mendorong pemikiran ke masa depan

10. Mendorong tercipatanya sikap positif akan perubahan.

Menurut David (2004:5), Model manajemen strategi terdiri dari tahap, yaitu: formulasi strategi, implementasi strategi, dan evaluasi strategi. Formulasi strategi terdiri dari pengembangan visi dan misi, mengidentifikasi lingkungan eksternal organisasi yaitu peluang dan ancaman, menentukan kelemahan dan kekuatan yang merupakan lingkungan internal organisasi, menghasilkan sasran jangka panjang, menghasilkan alternatif strategi, dan menetukan strategi yang akan dilaksanakan.

Menurut Dess dkk (1993:9), manajemen strategi terdiri dari tiga proses, yaitu: analisis strategi, formulasi strategi, dan implementasi strategi. Formulasi strategi yaitu proses dari pekerjaan rumah yang ditranformasikan ke dalam bentuk renana. Proses formulasi strategi dimulai dengan melihat lingkungan eksternal dengan menganalisis peluang dan ancaman, kemudian menilai lingkungn internal dengan menentukan kekuatan dan kelemahan.

\subsubsection{Tinjauan Tentang Bahasa}

Bahasa merupakan suatu ungkapan yang mengandung maksud untuk menyampaikan sesuatu kepada orang lain. Sesuatu yang dimaksudkan oleh pembicara bisa dipahami dan dimengerti oleh pendengar atau lawan bicara melalui bahasa yang diungkapkan.

Chaer dan Agustina (1995:14) fungsi utama bahasa adalah sebagai alat komunikasi. Hal ini sejalan dengan Soeparno (1993:5) yang menyatakan bahwa fungsi umum bahasa adalah sebagai alat komunikasi sosial. Sosiolinguistik memandang bahasa sebagai tingkah laku sosial (sosial behavior) yang dipakai dalam komunikasi sosial.

\subsubsection{Tinjauan Tentang Aksara}

Aksara merupakan suatu system symbol visual yang tertera pada kertas maupun media lainnya ( batu, kayu, kain, dll) untuk mengungkapkan unsur-unsur yang ekspresif dalam suatu bahasa. Istilah lain untuk menyebut akasara adalah system tulisan. Bakr H. Baheram dalam titik Pudjiastuti (1995:58) Pengertian lainya yaitu aksara 
adalah system tanda grafis yang digunakan manusia untuk berkomunikasi dan sedikit banyaknya mewakili ujaran.

\section{METODOLOGI PENELITIAN}

Penelitian ini menggunakan jenis penelitian Deskriptif kualitatif adalah salah satu penelitian yang termasuk dalam jenis penelitian kualitatif. Tujuan dari penelitian ini adalah untuk mengungkapkan langsung kejadian atau fakta,variabel dan keadaan yang terjadi saat penelitian berlangsung.

Lokasi penelitian merupakan tempat peneliti melakukan penelitian. Lokasi penelitaian ini dipilih menurut kriteriakriteria tertentu. Penelitian ini dilakukan di dalam lingkup wilayah Provinsi Lampung yaitu Dinas Pendidikan dan Kebudayaan Provinsi Lampung yang berada di jalan Drs. Warsito No 72 Sumur Putri Kecamatan Teluk Betung Utara Kota Bandar Lampung, 35215 .

Penelitian ini juga menggunakan sumber data primer dan data sekunder serta menggunakan teknik pengumpulan data dengan melakukan wawancara langsung kepada informan menggunakan pedoman wawancara, melakakukan observasi dengan cara pengamatan langsung di Dinas Pendidikan dan Kebudayaan Provinsi Lampung yang berada di jalan Drs. Warsito No 72 Sumur Putri Kecamatan Teluk Betung Utara Kota Bandar Lampung, 35215 .

Peneliti juga melakukan teknik analisis data yaitu reduksi data, penyajian data, dan verifikasi atau penyimpulan data dan terakhir menggunakan teknik keabsahan data.

\section{HASIL PENELITIAN DAN PEMBAHASAN}

\subsection{Gambaran Umum Dinas \\ Pendidikan dan Kebudayaan Provinsi Lampung}

Berdasarkan Rancangan Peraturan Gubernur Lampung Nomor Tahun 2014 tentang perubahan kedua atas Peraturan Gubernur Lampung Nomor 34 tahun 2010 tentang rincian tugas, fungsi dan tatakerja dinas-dinas daerah pada Pemerintah Provinsi Lampung sebagai berikut. Dinas Pendidikan dan Kebudayaan mempunyai tugas menyelenggarakan sebagian urusan pemerintahan provinsi di bidang pendidikan dan kebudayaan berdasarkan asas otonomi yang menjadi kewenangan, tugas dekonsentrasi dan tugas pembantuan yang diberikan pemerintah kepada Gubernur serta tugas lain sesuai dengan kebijakan yang ditetapkan oleh Gubernur berdasarkan peraturan perundang-undangan yang berlaku. Untuk menyelenggarakan tugas, Dinas Pendidikan dan Kebudayaan mempunyai fungsi:

1. perumusan kebijaksanaan operasional/teknis bidang pendidikan dan kebudayaan

2. penyelenggaraan koordinasi, sosialisasi, fasilitasi implementasi pelaksanaan kurikulum, sarana dan prasarana dan tenaga pendidik dan kependidikan lintas kabupaten/kota, pelayanan umum bidang kebudayaan serta penyelenggaraan perlindungan, pengembangan dan pemanfaatan kebudayaan;

3. penyelenggaraan supervisi, pengawasan, evaluasi dan pengendalian pelaksanaan kurikulum sarana dan prasarana, tenaga pendidik dan kependidikan dalam rangka pembinaan serta pembinaan dan pelaksanaan tugas di bidang kebudayaan;

4. pelaksanaan pengendalian mutu pendidikan dan pengembangan kebudayaan, nilai-nilai tradisi, 
pembinaan karakter dan pekerti bangsa, perfilman, kesenian, kesejahteraan dan kepurbakalaan;

5. pelaksanaan tugas lain yang diberikan oleh Gubernur sesuai dengan tugas dan fungsinya; dan

6. pelayanan administrative.

\subsubsection{Visi}

Mengacu kepada fungsi tersebut, pemerintah Provinsi Lampung periode 2015-2019 telah menetapkan visi: "Lampung Maju dan Sejahtera 2019". Berbagai upaya strategis untuk mencapai visi yang telah ditetapkan dituangkan kedalam beberapa misi. Salah satunya adalah misi 3, yaitu meningkatkan kualitas pendidikan, kesehatan, budaya masyarakat, dan toleransi kehidupan beragama.

\subsubsection{Misi}

Guna mendukung pencapaian visi di atas, maka pada tahun 2015-2019 Dinas Pendidikan dan Kebudayaan Provinsi Lampung menetapkan misi sebagai berikut :

1. Menyediakan pelayanan Pendidikan TK yang terjangkau ber-kesetaraan, dan bermutu;

2. Menyediakan pelayanan wajib belajar pendidikan dasar 9 tahun yang bermutu, terjangkau, dan berkesetaraan;

3. Menyediakan pelayanan pendidikan menengah yang ter-jangkau, berkesetaraan, dan bermutu;

4. Menyediakan pelayanan pendidikan nonformal dan informal yang terjangkau, berkesetaraan, dan bermutu sesuai kebutuhan masyarakat;

5. Menyediakan pelayanan pendidikan khusus dan menyeleng-garakan layanan pendidikan khusus;

6. Mewujudkan manajemen pelayanan pendidikan yang optimal, efektif, dan efisien;
7. Memelihara aset daerah bernilai budaya, dan melestarikan bahasa, seni, dan budaya daerah Lampung, dan

8. Meningkatkan daya saing regional. Misi tersebut merupakan kelanjutan dari lima pilar kebijakan pendidikan nasional tahun 2010-2014.

\subsection{Hasil Penelitian}

Berdasarkan hasil penelitian, peneliti menemukan bagaimana pelaksanaan Strategi Dinas Pendidikan dan Kebudayaan Provinsi Lampung dalam Melestarikan Bahasa dan Aksara Lampung

\subsubsection{Perencanaan antara dan Perencanaan Operasional}

Komponen dalam perencanaan strategi yang lebih berhubungan dengan kegiatankegiatan organisasi atau disebut juga dengan program yang akan dijalankan oleh Dinas Pendidikan dan Kebudayaan Provinsi Lampung. Program dalam penelitian ini digunakan untuk mengetahui pelaksanaan strategi yang dilakukan oleh Dinas Pendidikan dan Kebudayaan Provinsi Lampung dalam melestarikan bahasa dan aksara Lampung. Program merupakan kegiatan yang ada pada Dinas Pendidikan dan Kebudayaan Provinsi Lampung yang di dalam kegiatan tersebut juga terdapat partisipasi pihak-pihak lain yang terkait.

\subsubsection{Gaya Kepemimpinan, Motivasi dan Komunikasi}

Cara memimpin suatu organisasi sangat berpengaruh terhadap keaktifan dari organisasi tersebut. Cara pemimpin yang baik dan sesuai harus mampu untuk mengajak serta mendorong para bawahannya untuk dapat menjalankan misimisi organisasi agar tercapai visi organisasi.

\subsubsection{Manajemen Sumber Daya Manusia dan Kultur Organisasi}


Komponen sumber daya manusia dan kultur organisasi sangat penting untuk pencapaian tujuan-tujuan strategi. Sumber daya manusia memiliki peran penting dalam proses manajerial. Hal tersebut karena manusia itu sendiri adalah pelaksana utama dalam seluruh proses manajemen. Sumber daya manusia merupakan hal yang sangat pokok dan yang paling utama dalam menjalankan suatu organisasi. Tujuan organisasi agar dapat tercapai dengan baik, dibutuhkan sumber daya manusia memenuhi syarat-syarat dan kriteria organisasi. Manajemen sumber daya manusia menjadi salah satu unsur utama yang ada dalam implementasi strategi, karena hal tersebut berkaitan langsung dengan kinerja program Dinas Pendidikan dan Kebudayaan. Menjalankan suatu strategi sangat memerlukan adanya manajemen sumber daya manusia yang baik.

\subsubsection{Kendala-Kendala yang dihadapi Dinas Pendidikan dan Kebudayaan Dalam Melestarikan Bahasa dan Aksara lampung}

Kendala-kendala merupakan hal yang dapat menyebabkan jalannya program/kegiatan menjadi terhambat. Kendala-kendala yang dihadapi dalam pelaksanaan program/kegiatan Dinas Pendidikan dan Kebudayaan Provinsi Lampung adalah:

\section{Anggaran yang terbatas}

Anggaran merupakan hal yang sangat pokok dan yang paling utama dalam menjalankan suatu organisasi untuk mewujudkan tujuan. Keterbatasan Anggaran dalam upaya pelestarian bahasa dan aksara lampung merupakan salah satu kendala yang dihadapi Dinas Pendidikan dan Kebudayaan Provinsi Lampung.

2. Jumlah SDM yang ada di bidang kebudayaan
Jumlah pegawai Disdikbudpar Provinsi Lampung adalah 400 orang dengan latar belakang pendidikan pegawainya sebagai berikut :

\section{Tabel 4.1. Latar Belakang Pendidikan Pegawai}

\begin{tabular}{|c|c|c|}
\hline No & $\begin{array}{c}\text { Latar Belakang } \\
\text { Pendidikan }\end{array}$ & Jumlah \\
\hline 1 & S2 & 135 \\
\hline 2 & S1 & 211 \\
\hline 3 & SMA/Sederajat & 54 \\
\hline \multicolumn{2}{|c|}{ Jumlah } & 400 \\
\hline
\end{tabular}

Sumber: Disdikbudpar, 2019

Berdasarkan table diatas dapat diketahui bahwa jumlah pegawai dengan latar belakang pendidikan S2 adalah 135 orang, pegawai dengan latar belakang pendidikan S1 211 orang dan 54 orang pegawai latar belakang pendidikan SMA.

\subsection{Pembahasan}

Peneliti haruslah melakukan pembahasan dari hasil analisis penelitiann dan pada tahap ini peneliti melakukan evaluasi terhadap Dinas Pendidikan dan Kebudayaan Provinsi Lampung dalm melestarikan Bahasa dan aksara lampung. Peneliti akan melakukan pembahasan berdasarkan fokus penelitian yang telah ditetapkan serta data dari hasil penelitian yang diperoleh selama penelitian berlangsung. Adapun pembahasan mengenai Implementasi Strategi Dinas Pendidikan dan Kebudayaan Provinis Lampung dalam Melestarikan Bahasa dan 
Aksara Lampung akan dideskripsikan sebagai berikut:

\subsubsection{Perencanaan antara dan Perencanaan Operasional}

Berdasarkan hasil penelitian yang dilakukan oleh peneliti mengenai implementasi strategi di Dinas Pendidikan dan Kebudayaan Provinsi Lampung merupakan OPD (Organisasi Perangkat Daerah) yang mempunyai keterlibatan besar serta mempunyai peran penting dan tugas yang besar dalam menjaga keberadaan dan keberlangsungan Bahasa dan Aksara Lampung yang merupakan unsur kebudayaan daerah, Dinas Pendidikan dan Kebudayaan Provinsi Lampung memiliki strategi.

Komponen dalam perencanaan strategi yang lebih berhubungan dengan kegiatankegiatan organisasi atau disebut juga dengan program yang akan dijalankan oleh Dinas Pendidikan dan Kebudayaan Provinsi Lampung. Program dalam penelitian ini digunakan untuk mengetahui pelaksanaan strategi yang dilakukan oleh Dinas Pendidikan dan Kebudayaan Provinsi Lampung dalam melestarikan bahasa dan aksara Lampung.

Berdasarkan hasil penelitian yang diperoleh, peneliti menyimpulkan bahwa program yang dibuat oleh Dinas Pendidikan dan Kebudayaan Provinsi Lampung cukup baik namun belum maksimal. Hal ini dibuktikan dengan konten program yang terfokus pada pembelajaran aksara Lampung dan belum menyertakan seperti kamus bahasa Lampung atau konten bahasa Lampung didalamnya.

\subsubsection{Gaya Kepemimpinan, motivasi dan komunikasi}

Tercapainya suatu program yang dilaksanakan tidak lepas juga dari pengaruh para pemimpinnya. Dalam setiap organisasi pasti mengenal istilah kepemimpinan. Kepemimpinan menjadi salah satu modal utama disetiap keberhasilan atau kegagalan suatu organisasi.

Dibuktikan dengan Gaya kepemimpinan di Dinas Pendidikan dan Kebudayaan Provinsi Lampung lebih sering melakukan interaksi dalam komunikasi yang baik dan santun guna menciptakan pendekatan antara atasan dengan bawahan. Sehingga terjalin hubungan baik dan dapat bekerja sama dengan baik dalam mencapai tujuan organisasi.

Berdasarkan hasil penelitian di lapangan bahwa motivasi terhadap pegawai di Dinas Pendidikan dan Kebudayaan Provinsi Lampung masuk ke dalam beberapa faktor seperti halnya motivasi yang diberikan kepada pegawai untuk mencapai hasil yang baik, melakukan pekerjaan dengan baik dan semangat dalam bekerja, mengerjakan sesuatu untuk membantu organisasi mencapai tujuannya, serta adanya penerapan tukin tiap bulannya untuk memotivasi pegawai dalam bekerja. dan juga adanya teknologi fingerprint agar memotivasi pegawai untuk lebih disiplin.

Tujuan motivasi diberikan agar menumbuhkan semangat kerja dengan melakukan sepenuh hati karena melakukan dengan keikhlasan itu penting sehingga melihat pekerjaan itu adalah sesuatu yang menarik, melaksanakan tugas dengan tekad tidak menginginkan organisasi atau memiliki kinerja buruk.

\subsubsection{Sumber Daya Manusia dan Kultur Organisasi}

Menurut Heide dalam Heene (2010:181) Sumber daya manusia juga merupakan kunci yang menentukan perkembangan organisasi. Keberhasilan atau kegagalan 
implementasi suatu strategi akan bergantung pada dedikasi para partisipan perorangan yang merasa bertanggung jawab mewujudkan strategi tersebut ke dalam realitas.

Keberhasilan dan kinerja seseorang dalam suatu bidang pekerjaan banyak ditentukan oleh tingkat kompetensi, profesionalisme dan juga komitmennya terhadap bidang pekerjaan yang ditekuninnya. Sebuah organisasi dituntut untuk mampu meningkatkan kualitas sumber daya manusia yang ada. Kualitas sumber daya manusia banyak ditentukan oleh sejauh mana sistem yang ada di organisasi mampu menunjang dan memuaskan keinginan baik dari pegawai maupun dari organisasi.

Berdasarkan hasil penelitian diatas diketahui bahwa memanajemen sumber daya manusia di Dinas Pendidikan dan Kebudayaan Provinsi Lampung dapat dilihat melalui diterapkan pembagian kerja melalui struktur organisasi dan adanya aturan kerja atau prosedur kerja, adanya struktur yang jelas membuat para pegawai tidak kebingungan dalam melakukan pekerjaannya dan adanya prosedure kerja membuat pegawai mengerti aturan-aturan teknis dalam bekerja. Pegawai juga dituntut untuk selalu disiplin waktu dapat bermanfaat untuk produktivitas pegawai.

\section{KESIMPULAN DAN SARAN}

\subsection{Kesimpulan}

Adapun kesimpulan yang dapat peneliti ambil dalam Pelaksanaan Strategi Dinas Pendidikan dan Kebudayaan Provinsi Lampung Dalam Melestarikan Bahasa dan Aksara Lampung terbagi atas :

1. Pembelajaran aksara Lampung berbasis mobile (KaGaNga Mobile), program ini merupakan upaya meningkatkan pembinaan dan pengembangan bahasa dan aksara lampung melalui multimedia. Pemerintah melalui Dinas Pendidikan dan Kebudayaan dan UPTD BPTP Dinas Pendidikan dan Kebudayaan mencoba berinovasi melalui pengembangan sebuah aplikasi digital, pengembangan aplikasi ini melibatkan MGMP bahasa Lampung serta akademisi S2 bahasa Lampung dalam pengembangan kontennya, diciptakannya aplikasi ini dengan tujuan agar penggunanya (masyarakat) dapat belajar bahasa dan aksara Lampung dengan mudah melalui smartphone.

2. Gaya kemimpinan yang ada pada Dinas Pendidikan dan Kebudayaan Provinsi Lampung adalah gaya konsultatif yaitu lebih banyak melakukan interaksi dengan staf dan anggota organisasi. Fungsi pemimpin lebih banyak berkonsultasi, memberikan bimbingan, motivasi, memberi nasihat dalam rangka pencapaian tujuan.

3. Manajemen sumber daya manusia di Dinas Pendidikan dan Kebudayaan Provinsi Lampung dapat dilihat melalui diterapkan pembagian kerja melalui struktur organisasi dan adanya aturan kerja atau prosedur kerja, adanya struktur yang jelas membuat para pegawai tidak kebingungan dalam melakukan pekerjaannya dan adanya prosedure kerja membuat pegawai mengerti aturan-aturan teknis dalam bekerja.

\subsection{Saran}

Saran yang dapat penulis berikan antara lain adalah :

1. Dinas Pendidikan dan Kebudayaan Propinsi Lampung harus dapat meningkatkan aplikasi pembelajaran bahasa lampung yang sudah ada. Selain itu melalui publikasi aplikasi secara 
bertahap di sekolah - sekolah dan lembaga pemerintahan.

2. Penganggaran program dan kegiatan yang dapat mendukung pelaksanaan pengembangan aplikasi tersebut.

3. Pemenuhan Sumber Daya Manusia yang dapat mendukung pelaksanaan program dan kegiatan Dinas Pendidikan dan Kebudayaan Propinsi Lampung khususnya di bidang seni dan budaya lampung.

4. Komitmen pemerintah daerah dalam melestarikan Bahasa Lampung harus dapat dituangkan dalam perjanjian kinerja pemerintah sesuai dengan indicator kinerja yang telah ditetapkan sebelumnya.

\section{DAFTAR PUSTAKA}

\section{Sumber Buku}

Akdon.2011. Manajemen Strategi untuk Manajemen Pendidikan, Bandung: Alfabeta

Amirullah.2015.Manajemen Strategi (Teori dan Aplikasi). Jakarta: PT. Raja Grafindo Persada

Amir, Taufiq. 2011. Manajemen Strategik (Konsep dan Aplikasi). Jakarta: PT Raja Grafindo Persada.

B. Tregoe dan Johnn W. Zimmerman. 1980. Strategi Manajemen. Jakarta : Erlangga

David, Fred R. 2004. Manajemen Strategis, Edisi Bahasa Indonesia, Jakarta: PT. Indeks Kelompok Gramedia

Heene, Aime, dkk. 2010. Manajemen Startegik Keorganisasian Publik. Jakarta: Refika Aditama.

Martinet, Andre. 1987. Ilmu Bahasa: Pengantar. Yogyakarta: Kasinus
Moeloeng,Lexy

J.2007.Metodologi Penellitian

Kualitatif.Bandung:Rosdakarya

Moeloeng,Lexy

J.2010.Metodologi

Penellitian

Kualitatif.Bandung:Rosdakarya

Nawawi, Hadari.2012.Manajemen Strategi Organisasi Non Profit Bidang Pemerintahan.Yogyakarta:Gadjah Mada University Press.

Siagian,Sondang P.2005.Manajemen Stratejik Edisi Keenam.Jakarta:PT. Bumi Aksara

Siagian,Sondang P.2012.Manajemen Stratejik Edisi Keenam.Jakarta:PT. Bumi Aksara

Salusu, J.2006.Pengambilan Keputusan Strategik ntuk Organisasi Publik dan Organisasi Non Profit.Jakarta:PT. Gramedia Widiasarana

Sugiyono.2011.Metode Penelitian Kuantitatif, Kkualitatif dan $R \& D$.Bandung:Alfabeta

Umar, Husein. 2010. Desain Penelitian Manajemen Strategik. Jakarta. PT Rajagrafindo Persada

\section{Sumber Undang-Undang}

Peraturan Daerah nomor 2 tahun 2008, Tentang Pemeliharaan Kebudayaan Lampung

Peraturan Gubernur nomor 4 tahun 2011, Tentang Pengembangan, Pembinaan dan Pelestarian Bahasa dan Aksara Lampung

Peraturan Gubernur nomor 39 tahun 2014, Tentang Mata Pelajaran

Bahasa dan Aksara Lampung Sebagai Muatan Lokal Wajib Pada Jenjang 
Satuan Pendidikan Dasar dan Menengah.

\section{Sumber Skripsi}

Sari,Septiana.(2007).Komunikasi

Kelompok Masyarakat Suku Lampung di Kelurahan Negeri Sakti Kecamatan Gedong Tataan Kabupaten Pesawaran.Lampung:Universitas Lampung

Rifany, Tiara. (2016). Strategi Badan Narkotika Nasional Provinsi Lampung Dalam Menghadapi Lampung Zona
Merah Narkoba (Studi Pada Kalangan

Remaja) (Skripsi). Universitas Lampung. Bandar Lampung.

\section{Sumber Internet}

Sumber:http://www.kompasiana.com/kristi anadiputra/menyambut-kepunahanbahasalampung-ironi-bulanbahasa 5518e6ed813311fa719de0cc (diakses tanggal 20 Agustus tahun 2016 pukul 13.30 WIB)

Sumber:http://www.radarlampung.co.id/rea $\mathrm{d} /$ pendidikan/86348-guru bahasalampung-minim (diakses tanggal 20 Agustus 2016 pukul 13.30). 